\title{
Use of Inherited Differences among Strains of Inbred Mice to Study Genetic Determinants of Steroid Biosynthesis ${ }^{a}$
}

\author{
JOHN R. D. STALVEY ${ }^{b}$ and ANITA H. PAYNE \\ Reproductive Endocrinology Program \\ Departments of Obstetrics and Gynecology and \\ Biological Chemistry \\ The University of Michigan \\ Ann Arbor, Michigan 48109
}

Testosterone biosynthesis by Leydig cells is the result of extensive sequential enzymatic modification of the parent molecule, cholesterol. Genetic differences that exist between and within species can result in alterations of structure and/or activity of the enzymes responsible for metabolism of cholesterol to testosterone. Thus, the genetic differences in laboratory animals can be used to study the influence of variation in structure and/or activity of the enzymes on the production of testosterone. We have recently adopted this approach, using purified Leydig cells from genetically defined inbred mice, to study the relationships between maximal testosterone production and the activities of steroidogenic enzymes of the smooth endoplasmic reticulum (SER) that catalyze the synthesis of testosterone from pregnenolone.

Various strains of inbred mice were screened for differences in maximal testosterone production. Through this screening process it became apparent that Leydig cells from C57BL/10J (BL/10) and C57BL/6J (BL/6) mice produced twice as much testosterone in response to maximal hCG or dibutyryl-cAMP stimulation as did Leydig cells from DBA/2J (DBA) or $\mathrm{C} 3 \mathrm{H} / \mathrm{HeJ}(\mathrm{C} 3 \mathrm{H})$ mice. ' Furthermore, there was no correlation between maximal testosterone production per Leydig cell and the number of $\mathrm{LH}$ receptors per Leydig cell.' ${ }^{\prime}$ These observations indicated that these four strains would be useful to study steps distal to the formation of cAMP that might influence differences in testosterone production.

Leydig cells were purified from testes of $\mathrm{BL} / 10, \mathrm{BL} / 6, \mathrm{DBA}$, and $\mathrm{C} 3 \mathrm{H}$ mice. Decapsulated testes were completely dissociated by treatment with collagenase and Leydig cells were purified by centrifugation in a continuous $12-27 \%$ gradient of Metrizamide.' Maximal testosterone production was assessed by incubating cells for $2 \mathrm{hr}$ at $34^{\circ} \mathrm{C}$ with a saturating concentration of hCG. Testosterone was measured in cells plus medium by radioimmunoassay. Activities of $3 \beta$-hydroxysteroid dehydrogenase-isomerase ( $3 \beta \mathrm{HSD}), 17 \alpha$-hydroxylase, $\mathrm{C}_{17-20}$ lyase, and 17-ketosteroid reductase were determined by incubating homogenized Leydig cells for $5 \mathrm{~min}$ at $37^{\circ} \mathrm{C}$ with saturating concentrations of the appropriate cofactor and the appropriate ${ }^{3} \mathrm{H}$-labeled substrate and measuring the amount of ${ }^{3} \mathrm{H}$-labeled product formed.

a Supported by National Institute of Child Health and Human Development grants HD08358 and HD-17916, and a National Research Service Award HD-06392 to J.R.D.S.

${ }^{b}$ Address correspondence to: John R. D. Stalvey, Steroid Research Unit, L 1221 Women's Hospital, The University of Michigan, Ann Arbor, MI 48109. 
TABLe 1. Maximal Testosterone Production in Response to hCG Stimulation and the Activity of the Smooth Endoplasmic Reticular Steroidogenic Enzyme, $3 \beta$-Hydroxysteroid dehydrogenase-isomerase, in Leydig Cells from Four Strains of Inbred Mice

\begin{tabular}{|c|c|c|}
\hline Strain & $\begin{array}{l}\text { Testosterone Production } \\
\text { (ng/106 Leydig cells } / 2 \mathrm{hr} \text { ) }\end{array}$ & $\begin{array}{c}3 \beta \text {-Hydroxysteroid dehydrogenase- } \\
\text { isomerase Activity } \\
\text { (pmol } / \mathrm{min} / 10^{6} \text { Leydig cells) }\end{array}$ \\
\hline $\begin{array}{l}\text { C57BL/10J } \\
\text { (3) }\end{array}$ & $1168 \pm 126^{a}$ & $1683 \pm 209^{x}$ \\
\hline $\begin{array}{l}\text { C57BL/6J } \\
\text { (6) }\end{array}$ & $1255 \pm 97^{a}$ & $1142 \pm 111^{y}$ \\
\hline $\begin{array}{l}\mathrm{DBA} / 2 \mathrm{~J} \\
(6)\end{array}$ & $640 \pm 76^{b}$ & $758 \pm 41^{2}$ \\
\hline$\underset{(3)}{\mathrm{C} 3 \mathrm{H} / \mathrm{HeJ}}$ & $655 \pm 59^{b}$ & $697 \pm 69 z$ \\
\hline
\end{tabular}

For statistical analysis, data were subjected to analysis of variance and Duncan's new multiple range test $(\alpha=0.05)$.

Groups sharing the same superscript $\left(2-b\right.$ or $\left.{ }^{x-2}\right)$ are not significantly different.

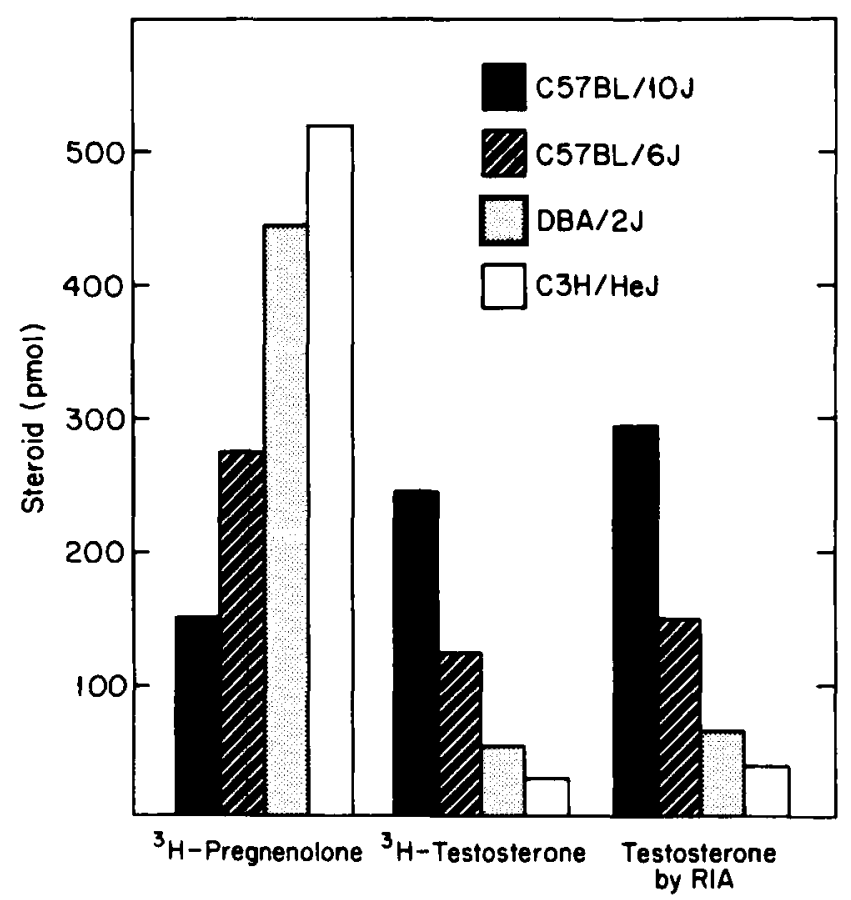

FIGURE 1. Testosterone production by intact Leydig cells incubated with pregnenolone. Equivalent numbers of whole Leydig cells were incubated for $2 \mathrm{hr}$ at $34^{\circ} \mathrm{C}$ with $1 \mu \mathrm{M}$ $\left[{ }^{3} \mathrm{H}\right]$ pregnenolone or $1 \mu \mathrm{M}$ nonradioactive pregnenolone. The group of bars to the left represent unmetabolized $\left[{ }^{3} \mathrm{H}\right]$ pregnenolone. The group of bars in the middle and to the right represent the amount of testosterone produced as measured by determining the amount of $\left[{ }^{3} \mathrm{H}\right]$ testosterone formed from $\left[{ }^{3} \mathrm{H}\right]$ pregnenolone or the amount of nonradioactive testosterone formed from nonradioactive pregnenolone. The latter value was measured by radioimmunoassay. 
Leydig cells from $\mathrm{BL} / 10$ and $\mathrm{BL} / 6$ mice produced twice as much testosterone as did Leydig cells from DBA and C3H mice (TABLE 1). Of the SER enzymes, only $3 \beta$ HSD activity differed significantly among Leydig cells from the four strains (TABLE 1), and there was a significant interstrain correlation $(r=0.82)$ between maximal testosterone production and $3 \beta \mathrm{HSD}$ activity. When intact Leydig cells from the four strains were incubated for $2 \mathrm{hr}$ with equal concentrations of pregnenolone, Leydig cells from $\mathrm{BL} / 10$ and $\mathrm{BL} / 6$ mice, the strains that exhibited high hCG-stimulated testosterone production, metabolized considerably more of the added pregnenolone to testosterone than did Leydig cells from DBA and $\mathrm{C} 3 \mathrm{H}$ mice, the strains that exhibited low hCG-stimulated testosterone production (FIGURE 1).

The inverse relationship between unmetabolized pregnenolone and the amount of testosterone produced, in addition to the interstrain correlation between hCG-stimulated testerone and $3 \beta$ HSD activity, indicates that $3 \beta H S D$ activity is important in maximal testosterone production. Also, these results suggest that genetic analysis of the steroidogenic enzymes can be used to study the regulation of testosterone biosynthesis. Further studies using standard genetic crosses as well as recombinant inbred lines should allow us to establish whether or not there is a causal relationship between $3 \beta \mathrm{HSD}$ activity and maximal testosterone production.

\section{REFERENCE}

1. Stalvey, J. R. D. \& A. H. Payne. 1983. Endocrinology 112:1696-1701. 